\title{
Precipitation, Soils and Herbage Production on South- east Wyoming Range Sites
}

\author{
R.H. HART AND M.J. SAMUEL
}

\begin{abstract}
Herbage production and precipitation were determined at 13 locations in $\mathbf{4 8 3}$ ha of mixed grass range 1975-1979; production was determined at all locations 1982-1983, but precipitation was measured only at the main weather station. Vegetation and herbage production were more uniform on sites with similar subsoil than on sites with similar surface soil, the usual basis for site classification. Within any year, herbage production on similar sites was not correlated with spatial distribution of precipitation. Across years 1975-1979 and 1982-1983, herbage production on sites with sandy subsoil was correlated with March-April weather station precipitation $\left(r^{2}=0.866^{* *}\right)$ and March-April plus May-August precipitation $\left(R^{2}=0.95^{* *}\right)$. Herbage production on sites with loamy subsoil was not significantly correlated with precipitation in March-April $\left(r^{2}=0.32\right)$ or any other period.
\end{abstract}

Variation in precipitation from year to year is reflected in variations in range herbage production. Hart and Carlson (1975) reviewed 6 studies in which linear regressions of total annual herbage production on precipitation were calculated; coefficients of determination $\left(r^{2}\right)$ were as high as 0.61 . Rauzi (1964) found that annual herbage yields southeast of Cheyenne, Wyo., were correlated with May-June $\left(r^{2}=0.46\right)$ and April-September $\left(r^{2}=0.57\right)$ precipitation. However, less attention has been paid to variations in herbage production caused by spatial variation in precipitation in a single year.

We became concerned with such variation in 1974, when we began a grazing study (Hart et al. 1983) on 483 ha, or nearly 2 sections, of mixed-grass range northwest of Cheyenne, Wyo. The study area was divided first into 2 and later into 3 pastures, each with a different stocking rate treatment. We wanted to determine if the response to stocking rate was being confounded by differences in herbage production, caused by differences in precipitation, among the 3 pastures.

\section{Materials and Methods}

We established a network of range gauges spaced $0.8 \mathrm{~km}(0.5 \mathrm{mi})$ apart over the study area in 1975 (Fig. 1). The plastic gauges were wedge-shaped in cross-section; this magnified the amount of water caught during light rains, so small amounts could be read more accurately. Precipitation in each gauge was recorded and the gauges emptied after each rain- or snowfall from 1 May to 30 September 1975 through 1979. Precipitation from 1 October to 30 April was measured in a standard Weather Service rain gauge at the headquarters of the High Plains Grasslands Research Station, about $0.6 \mathrm{~km}$ south of the south boundary of the study area.

In the spring of 1975 , we established 30 by $23-\mathrm{m}$ macroplots on the major soil types in the study area. Soil types were identified by the preliminary soil survey of Rauzi et al. (1976). A more detailed soil survey (Stevenson et al. 1984) realigned some soil type boundaries. Exclosures were randomly placed outside a different corner of each macroplot annually, but remained on the same soil, slope and plant community (Fig. 2).

Exclosures were pyramidal with a frame of $2-\mathrm{cm}$-wide angle iron

\footnotetext{
Authors are agronomist and botanist, Agricultural Research Service, U.S. Dep. of Agriculture, High Plains Grasslands Research Station, 8408 Hildreth Road, Cheyenne, Wyoming 82009.

Manuscript accepted March 19, 1985.
}

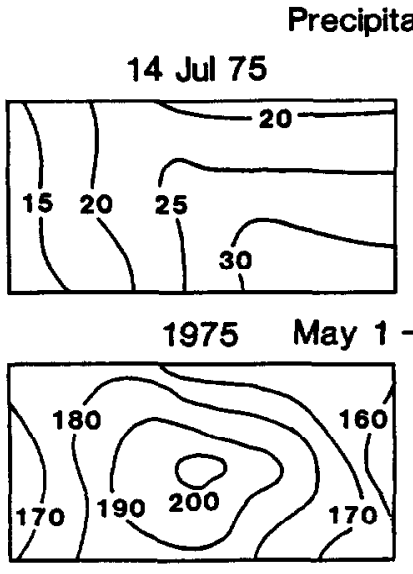

1977

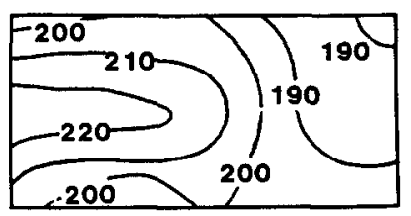

1979

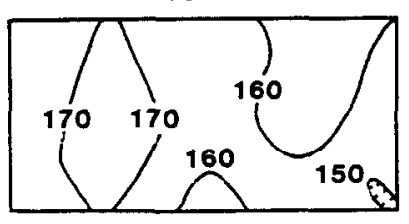

Elevation, $\mathrm{m}$
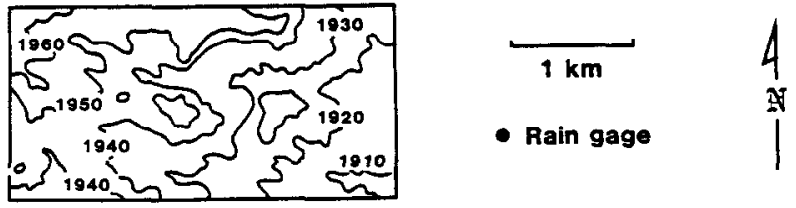

Fig. 1. Typography of and rain gauge locations on the study area, and distribution of precipitation by 5-year mean, 1975-79 growing seasons (1 May-30 Spetember), and 2 selected storms.

covered with 5- by $10-\mathrm{cm}$ wire mesh. Exclosures were about $1 . \mathrm{m}$ long, $1.2 \mathrm{~m}$ wide, and $0.9 \mathrm{~m}$ high. Steel stakes held them in place during the grazing season. In August of each year, at the estimated time of peak standing crop, exclosures were removed and 2 frames 30 by $60 \mathrm{~cm}$ were placed at random on the area formerly covered by the exclosures. Herbage was clipped to ground level by species or species groups, dried at $60^{\circ} \mathrm{C}$, and weighed to the nearest $0.1 \mathrm{~g}$. Species or species groups are western wheatgrass (Agropyron smithii Rydb.), blue grama (Bouteloua gracilis [H.B.K.] Lag. ex Griffiths), needleandthread (Stipa comata Trin. \& Rupr.), sedges (mostly, Carex eleocharis Bailey with some Carex filifolia Nutt.), other grasses, and forbs. 


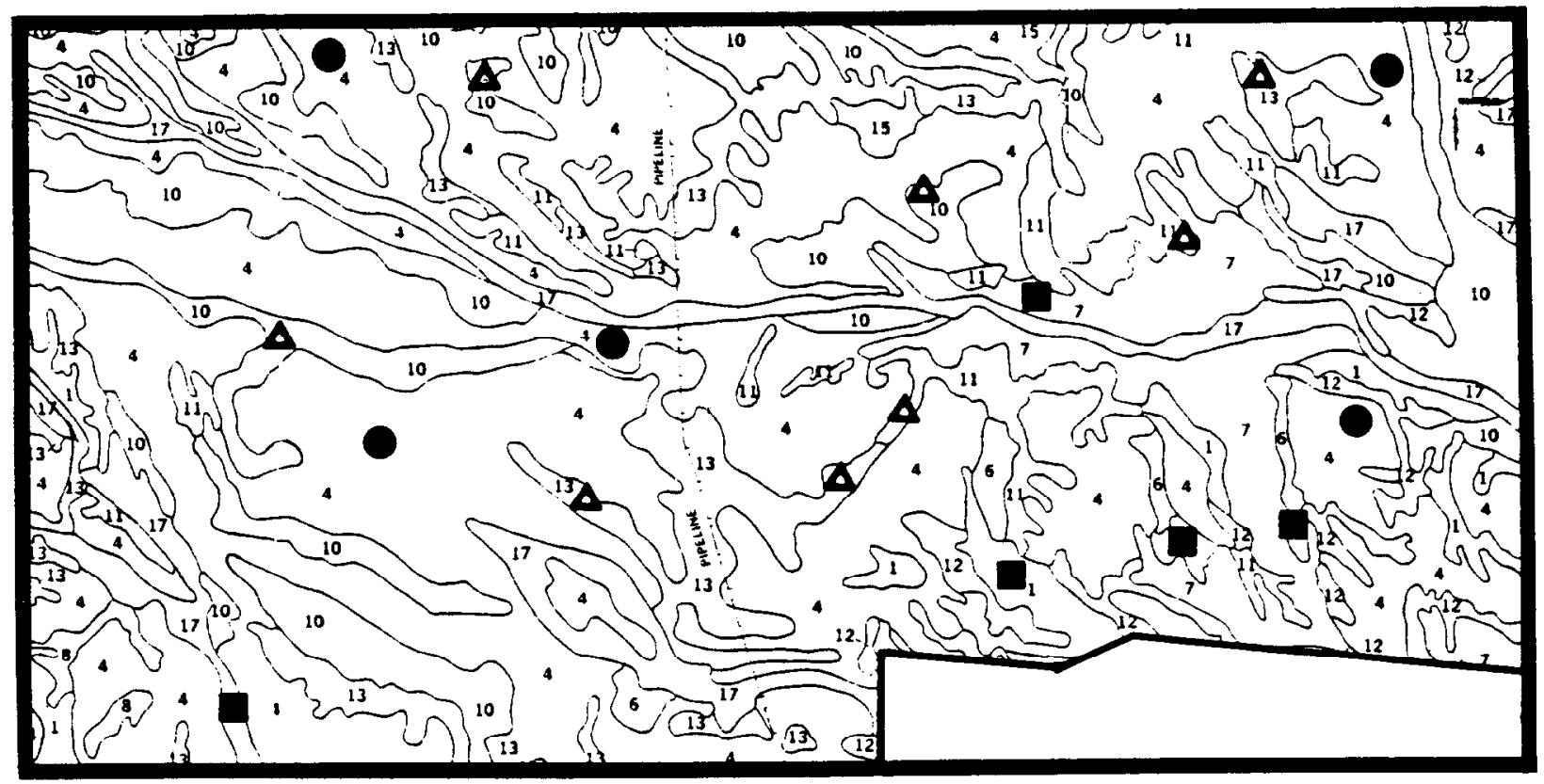

\section{Exclosures on:}
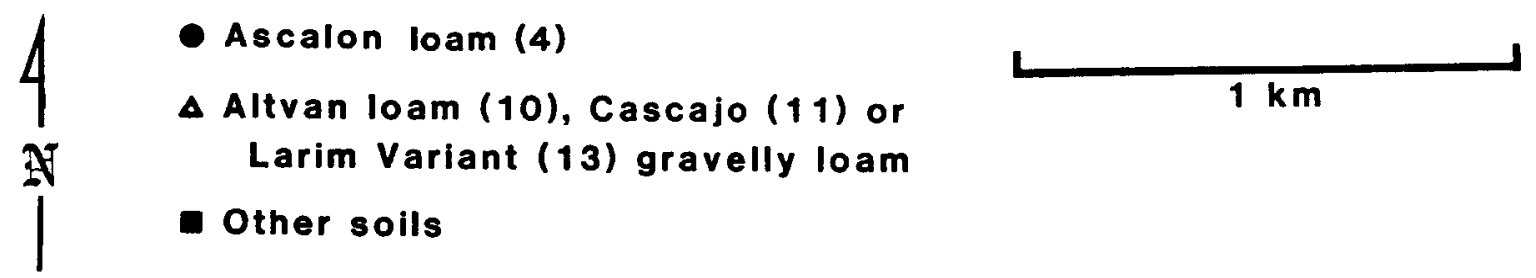

Fig. 2. Location of exclosures for determining herbage production.

Results will be reported only from Ascalon and Altvan (Aridic Argiustolls) loams, and Cascajo (Aridic Calciorthid) and Larim Variant (Ustollic Haplargid) gravelly loams. Typical texture profiles of these 4 soils, which cover about $83 \%$ of the study area, are shown in Fig. 3. The soil at any site may differ slightly from the typical profile. Site classification, slope, and number of exclosures are shown in Table 1. Of the other soil types, Ascalon Variant loam was represented by 2 exclosures so close together there was little difference between them in precipitation. Only 1 exclosure each was located on Nucla and Albinas loams and Aberone Variant gravelly loam; no exclosures were on Epping silt loam and Manter fine sandy loam.

Table 1. Characteristics of four soil types and associated vegetation.

\begin{tabular}{|c|c|c|c|c|}
\hline Measurement & Ascalon loam & Altvan loam & Cascajo gravelly loam & Larim variant gravelly loam \\
\hline \multicolumn{5}{|c|}{ 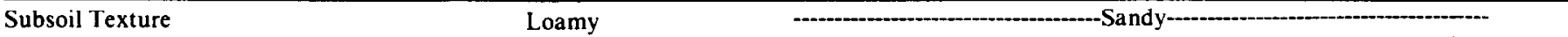 } \\
\hline Range site & Loamy & Loamy & Very shallow & Gravelly loamy \\
\hline Slope, \% & $0-3$ & $3-6$ & $6-15$ & $6-15$ \\
\hline Number of exclosures & 5 & 3 & 2 & 3 \\
\hline Forage yield, kg DM/ha & $1100 \mathrm{a}$ & $930 \mathrm{~b}$ & $890 \mathrm{~b}$ & $840 \mathrm{~b}$ \\
\hline \multicolumn{5}{|c|}{ Species composition by weight, percent } \\
\hline Western wheatgrass & $14 \mathrm{a}$ & $11 \mathrm{a}$ & $13 \mathrm{a}$ & $9 \mathrm{a}$ \\
\hline Blue grama & $56 \mathrm{ab}$ & $47 \mathrm{~b}$ & $50 \mathrm{ab}$ & $60 \mathrm{a}$ \\
\hline Needleleaf sedge & $14 a$ & $17 \mathrm{a}$ & $14 \mathrm{a}$ & $12 \mathrm{a}$ \\
\hline Needleandthread & $4 \mathrm{~b}$ & $11 \mathrm{a}$ & $12 \mathrm{a}$ & $6 \mathrm{ab}$ \\
\hline Other graminoids & $3 a$ & $2 \mathbf{a}$ & $4 \mathrm{a}$ & $4 \mathrm{a}$ \\
\hline Forbs & $8 \mathrm{a}$ & $13 a$ & $8 a$ & 8 a \\
\hline \multicolumn{5}{|c|}{ Species frequency, percent of $5 \times 5 \mathrm{~cm}$ squares; } \\
\hline Western wheatgrass & $26 \mathrm{a}$ & $14 b$ & $18 \mathrm{ab}$ & $13 \mathrm{~b}$ \\
\hline Blue grama & $82 a$ & $76 \mathrm{a}$ & $78 \mathrm{a}$ & $78 \mathrm{a}$ \\
\hline Needleleaf sedge & $54 \mathrm{a}$ & $46 \mathrm{a}$ & $42 \mathrm{a}$ & $45 \mathrm{a}$ \\
\hline \multicolumn{5}{|c|}{ Species frequency, percent of $41 \times 41 \mathrm{~cm}$ squares; } \\
\hline Needleandthread & $52 \mathrm{a}$ & $58 \mathrm{a}$ & $48 \mathrm{a}$ & 53 a \\
\hline
\end{tabular}

a, h Figures in the same row followed by the same letter are not significantly different $(p<0.05)$ as determined by t-test 
Analyses of variance and $t$-tests for means with unequal subclass numbers were used to compare yield and botanical composition on the 4 major soil types. Linear regression related herbage production to precipitation amounts.

\section{Results and Discussion}

The 4 soils were divided into 2 groups, according to similarities in yield and botanical composition of the associated vegetation. Altvan, Cascajo, and Larim Variant were grouped, because singleyear or 5-year-mean yields did not differ significantly among these 3 soils (Table 1). Blue grama made up less of the herbage yield on Altvan than on Larim Variant, but frequency of blue grama was the same on both soils. No other differences in botanical composition were found among these 3 soils, all with sandy subsoils (Fig. 3). However, the 5-year-mean herbage yields on Ascalon, with a loamy subsoil, were higher than yields on Altvan, Cascajo, or Larim Variant, as were the single-year yields 1975-1978 (Table 2). Needleandthread made up less of the herbage production on Ascalon than on Altvan or Cascajo, and western wheatgrass occurred more frequently on Ascalon than on Altvan or Larim Variant (Table 1).

Although Ascalon and Altvan are both classified as loamy range sites, they differ more in herbage production and composition than do Altvan and Cascajo, which are, respectively, loamy and very shallow sites. Site classifications based only on surface texture must be interpreted cautiously.

The range in May-September precipitation across the 15 study area gauges was as large as $20 \%$ of the mean in 1975 and as small as $8 \%$ in 1979 (Table 2). When 1975-1979 mean precipitation was calculated for each gauge, the range in these means was $11 \%$ of the overall mean. For single intense storms, the range could be much larger; $78 \%$ of the mean on 14 July 1975 and $73 \%$ on 31 July 1979. Distribution varied with storms and years; no correlation between topography and distribution was apparent.

Herbage production was more variable within each year than was May-September precipitation. The range was as high as $72 \%$ of the mean on Altvan, Cascajo, and Larim Variant in 1978, to as low as $30 \%$ of the mean on Ascalon in 1976 (Table 2). Within years and soil groups, herbage production was not significantly correlated with May-August precipitation; no $r^{2}$ exceeded 0.17 . This reflects in part the small variation in precipitation relative to the variation in production. Any differences in herbage production among pastures were assumed not to be caused by differences in precipitation.

Among years, herbage production on Altvan, Cascajo, and Larim Variant, including 1982 and 1983 data, was not correlated with May-August precipitation (Table 3). Because the network of rain gauges had been taken down at the end of 1979, we could correlate only mean production with precipitation records from the headquarters gauge. However, correlation of herbage yield with March-April precipitation was high $\left(r^{2}=0.86\right)$, and multiple

Table 2. Precipitation and herbage production on two groups of soils.

\begin{tabular}{|c|c|c|c|c|c|c|c|c|c|c|}
\hline Measurement & & 1974 & 1975 & 1976 & 1977 & 1978 & 1979 & 1981 & 1982 & 1983 \\
\hline \multicolumn{11}{|l|}{ Precipitation, $\mathrm{mm}$} \\
\hline March-April! & & - & 45 & 56 & 78 & 37 & 77 & - & 18 & 250 \\
\hline \multirow[t]{2}{*}{ May-September ${ }^{2}$} & Mean & - & 210 & 285 & 253 & 254 & 308 & - & 426 & 286 \\
\hline & Range, percent of mean & - & 20 & 11 & 19 & 9 & 8 & - & - & - \\
\hline \multicolumn{2}{|c|}{$\begin{array}{l}\text { March-September } \\
\text { Herbage Production, kg/ha }\end{array}$} & 195 & 225 & 341 & 331 & 291 & 385 & 376 & 444 & 356 \\
\hline \multirow[t]{2}{*}{ Ascalon } & Mean & - & 1120 & 1090 & 1240 & 1080 & 1020 & - & 1140 & 1240 \\
\hline & Range, percent of mean & - & 57 & 30 & 43 & 48 & 46 & - & - & - \\
\hline \multirow{2}{*}{$\begin{array}{l}\text { Altvan Cascajo, } \\
\text { \& Larim Variant }\end{array}$} & Mean & - & 860 & 880 & 850 & 860 & 980 & - & 950 & 1430 \\
\hline & Range, percent of mean & - & 39 & 31 & 36 & 72 & 48 & - & - & - \\
\hline
\end{tabular}

'Headquarters gauge.

2Study area gauges 1975-1979, headquarters gauge 1974 and 1981-1983. 
Table 3. Regression of annual herbage production (H, $\mathrm{kg} / \mathrm{ha}$ ) on precipitation ( $(\mathrm{m}, \mathrm{mm})$ in different periods at Headquarters rain gauge.

\begin{tabular}{ll}
\hline Soils and regression equations & $r^{2}$ or $R^{2}$ \\
\hline Altvan, Cascajo, and Larim Variant & \\
\hline$H=772+2.49 P_{\text {Mar-Apr }}$ & $0.86^{* *}$ \\
$H=831+0.49 P_{\text {May-Aug }}$ & 0.03 \\
$H=273+1.89 P_{\text {Mar-Aug }}$ & $0.76^{* *}$ \\
$H=497+2.61 P_{\text {Mar-Apr }}+0.92 P_{\text {May-Aug }}$ & $0.95 * *$ \\
Ascalon & \\
\hline$H=1083+0.60 P_{\text {Mar-Apr }}$ & 0.32 \\
$H=1155-0.086 P_{\text {May-Aug }}$ & 0.01 \\
$H=1001+0.35 P_{\text {Mar-Aur }}$ & 0.17 \\
$H=1079+0.60 P_{\text {Mar-Apr }}+0.013 P_{\text {May-Aug }}$ & 0.32 \\
\hline
\end{tabular}

correlation with March-April and May-August precipitation accounted for $95 \%$ of the variation in yield. Correlation with March-August total precipitation was not as high as with MarchApril and May-August separately in multiple regression, nor even as high as with March-April precipitation. The high correlation of annual herbage production with early-season precipitation has been noted by other researchers. Rauzi (1964) found that MayJune precipitation accounted for nearly as much of the variation in production as did April-August precipitation. Murphy (1970) reported that rainfall from 1 to 20 November was the best predictor of forage yields from California winter annual range; adding precipitation from the preceding season did not increase the coefficient of determination significantly. On Ascalon, the relationships of production and precipitation were similar, but the correlations were not significant, and coefficients in the regression equations were much smaller than could be accounted for by higher production.

Correlation of production with precipitation was good on soils with sandy subsoils and therefore little water storage capacity; plants growing on such soils were dependent on current rainfall. On a soil with loamy subsoil and higher water storage capacity, current rainfall was less important and stored water from past rains had some impact. On such soils, a more complex water-balance model (Wight and Hanks 1981) might be needed to predict herbage production. Much of the variation in production must have come from differences within soils in water holding capacity, as determined by texture and depth of soil horizons, and from differences in plant communities.

Even though spatial variation in May-September precipitation had little impact on herbage production, it may be important in determining runoff and soil loss. Osborn et al. (1980) noted that runoff volume was strongly correlated with total rainfall, and Johnson and Smith (1978) found that runoff and sediment yields increased not only with increasing total annual precipitation, but with increasing precipitation from individual storms.

\section{Literature Cited}

Dean, J.D., and W.M. Snyder. 1977. Temporally and areally distributed rainfall. J. Irr. Drain. Div., Proc., Amer. Soc. Civil Eng. 107:221-229.

Hart, R.H., and G.E. Carlson. 1975. Agricultural implications of climatic change-Agronomic implications-Forages. p. 4-163 to 4-173, 4-237 to 4-246 In: Impacts of Climatic Change on the Biosphere: Part 2-Climatic Effects. Dep. of Transportation, Climatic Impact Assessment Program, Washington, D.C.

Hart, R.H., J.W. Waggoner, Jr., D.H. Clark, C.C. Kaltenbach, J.A. Hager, and M.B. Marshall. 1983. Beef cattle performance on crested wheatgrass plus native range vs. native range alone. J. Range Manage. 36:38-40.

Hyder, D.N., R.E. Bement, E.E. Remmenga, and C. Terwilliger, Jr. 1965. Frequency sampling of blue grama range. J. Range Manage. 18:90-93.

Johnson, C.W., and J.P. Smith. 1978. Sediment characteristics and transport from northwest rangeland watersheds. Trans. Amer. Soc. Agr. Eng. 21:1157-1162, 1168 .

Murphy, A.H. 1970. Predicted forage yield based on fall precipitation in California annual grasslands. J. Range Manage. 23:363-365.

Osbom, H.B., E.D. Shirley, D.R. Davis, and R.B. Koehler. 1982. Model of time and space distribution of rainfall in Arizona and New Mexico. USDA-SEA-ARM-W-14. Gov. Print. Office, Washington, D.C.

Rauzi, F. 1964. Late-spring herbage production on shortgrass rangeland. J. Range Manage. 17:210-212.

Rauzi, F., A. Stevenson, and C. McAfee. 1976. A preliminary report on range site and condition for two native pastures at the High Plains Grasslands Research Station Cheyenne, Wyoming. Univ. Wyoming Agr. Exp. Sta. Res. J. 103.

Stevenson, A., R.E. Baumgartner, and G.E. Schuman. 1984. High Plains Grasslands Research Station-Detailed soil survey. Univ. Wyoming Agr. Exp. Sta. Pub. 1-84/1C/3.62.

Wight, J.R., and R.J. Hanks. 1981. A water-balance, climate model for range herbage production. J. Range Manage. 34:307-311.

\title{
Coming Publication of the Society for Range Management
}

\section{Range Research: Basic Problems and Techniques}

\author{
edited by C. Wayne Cook and James Stubbendieck
}

This major revision of an earlier publication of the National Academy of Science presents steps in research planning, evaluation of results, and methods and procedures in range research, including sampling techniques and experimental design. Inventorying and evaluating habitat factors are dealt with in a detailed manner, including measurement of vegetation cover, biomass, nutrient content, diversity, vertical structure, and biomass. Methods of studying vegetation, roots, herbage and browse utilization, livestock management in research, and research in rangeland hydrology and rangeland economics are discussed in this book of nearly 400 pages.

Illustrations, an index, and excellent lists of citations reflecting current developments make the hardbound book outstanding as a text and life-long reference book.

The book is scheduled for mid-January completion and will be available from the Society for Range Management, Denver, Colorado 